VIDEO Spinal myoclonus following herpes zoster radiculitis

A. Estraneo, MD; A.M. Saltalamacchia, NPhT; and

V. Loreto, $M D$, Telese (BN), Italy

A 69-year-old man with Parkinson disease and ischemic heart disease presented with spontaneous jerks in his right upper limb 2 weeks after right upper limb herpes zoster (at C5-C6, and partly C7).

On examination he had resting and postural irregular, brief myoclonic jerks of his upper limb, producing movements of internal rotation and adduction at the shoulder, pronation of forearm,

Disclosure: The authors report no conflicts of interest.

Address correspondence and reprint requests to Dr. A. Estraneo, Salvatore Maugeri Foundation, IRCCS Via Bagni Vecchi, 82037 Telese Terme (BN), Italy; e-mail: aestraneo@fsm.it and medial flexion of wrist at a rate of 4 to $12 /$ minute (video). The main muscles involved (clavicular fibers of pectoralis major, teres major, pronator teres, flexor carpi ulnaris) largely corresponded to the root levels affected by the zoster. A video-EEG-EMG did not show any epileptiform activity. Motor and sensory conduction velocity and F-wave of median and ulnar nerves were normal. MRI of spine was precluded because of his pacemaker. Clonazepam treatment was poorly tolerated, so levetiracetam $250 \mathrm{mg}$ BID was started, and myoclonus completely ceased after 7 days.

Spinal myoclonus associated with herpes zoster radiculitis is rare, probably because with treatment of the virus using acyclovir the myoclonus does not develop or disappears. ${ }^{1}$ Nonetheless, in our patient the segmental myoclonus did not remit with antiviral treatment and clearly improved with levetiracetam ${ }^{2}$.

Copyright () 2007 by AAN Enterprises, Inc.

1. Hoehn MM, Cherington M. Spinal myoclonus. Neurology 1977;27:942946.

2. Keswani SC, Kossoff EH, Krauss GL, Hagerty C. Amelioration of spinal myoclonus with levetiracetam. J Neurol Neurosurg Psychiatry 2002;73: $457-458$. 


\title{
Neurology
}

\section{Spinal myoclonus following herpes zoster radiculitis}

\author{
A. Estraneo, A. M. Saltalamacchia and V. Loreto \\ Neurology 2007;68;E4 \\ DOI 10.1212/01.wnl.0000246115.54997.1b
}

This information is current as of January 29, 2007

$\begin{array}{ll}\begin{array}{l}\text { Updated Information \& } \\ \text { Services }\end{array} & \begin{array}{l}\text { including high resolution figures, can be found at: } \\ \text { http://n.neurology.org/content/68/5/E4.full }\end{array} \\ \text { Supplementary Material } & \begin{array}{l}\text { Supplementary material can be found at: } \\ \text { http://n.neurology.org/content/suppl/2007/01/26/68.5.E4.DC1 }\end{array} \\ \text { This article cites } 2 \text { articles, } 2 \text { of which you can access for free at: } \\ \text { http://n.neurology.org/content/68/5/E4.full\#ref-list-1 } \\ \text { This article, along with others on similar topics, appears in the } \\ \text { following collection(s): } \\ \text { All Spinal Cord } \\ \text { http://n.neurology.org/cgi/collection/all_spinal_cord } \\ \text { Myoclonus; see Movement Disorders/myoclonus } \\ \text { http://n.neurology.org/cgi/collection/myoclonus_see_movement_disord } \\ \text { ers-myoclonus } \\ \text { Spinal cord infection } \\ \text { http://n.neurology.org/cgi/collection/spinal_cord_infection } \\ \text { Information about reproducing this article in parts (figures,tables) or in } \\ \text { its entirety can be found online at: } \\ \text { http://www.neurology.org/about/about_the_journal\#permissions } \\ \text { Information about ordering reprints can be found online: } \\ \text { Permissions \& Licensing } \\ \text { http://n.neurology.org/subscribers/advertise }\end{array}$

Neurology ${ }^{\circledR}$ is the official journal of the American Academy of Neurology. Published continuously since 1951, it is now a weekly with 48 issues per year. Copyright . All rights reserved. Print ISSN: 0028-3878. Online ISSN: 1526-632X.

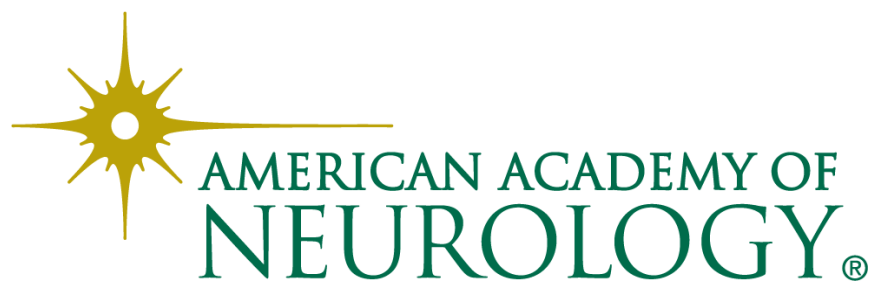

